\title{
Auditing the Auditors: The Audit Oversight Board and Regulating Audit Quality in Malaysia*
}

\author{
Hashanah Ismail, Mazlina Mustapha \\ Universiti Putra Malaysia, Selangor, Malaysia
}

\begin{abstract}
The setting-up of the Malaysian Audit Oversight Board (AOB) in 2010 under the Securities Commission Amendment Act 2010 has extended the role of regulators into the statutory audit domain for public listed companies. Although the auditing profession in Malaysia has International Auditing Standards as prescribed minimum level of quality in the delivery of audit assurance services, self-regulation by the profession alone appears inadequate to ensure the delivery of quality audit services. With co-regulation, auditors now are monitored not just by the profession but also by a new statutory body with considerable regulatory powers to sanction auditors where quality of the audit process has been found wanting. This study solicits the opinions of auditors on their expectations of what the new regulator can achieve. Based on interviews with a sample of 30 auditors, the study finds that the majority believe that audit quality will be taken to a new level following AOB's remit of registration of auditors, compliance inspection with International Standard on Quality Control (ISQC), monitoring of financial statement quality, and its power of sanctions. A review of AOB's early years' inspection confirms these expectations.
\end{abstract}

Keywords: auditing, statutory audit, International Standard on Quality Control (ISQC), auditing standards, Audit Oversight Board (AOB), audit regulation

\section{Introduction}

External auditors ensure integrity in the financial reporting process through independent audits of financial statements. Thus, audited financial statements are deemed more credible than unaudited ones by virtue of the assurance given by an independent expert, the external auditor. In Malaysia, audits must be performed according to a prescribed minimum quality level found in the auditing standards approved by the Malaysian Institute of Accountants (MIA), and any departure or non-compliance with approved auditing standards may result in a sub-standard audit and non-compliance must be justified. Whilst external auditors monitor the quality of financial reports prepared by companies, who monitors the auditors? The quality of the external audit is monitored by the profession, which makes the audit profession a self-regulating profession. However, in 2010, an additional layer of regulation of the external audit was created when the Audit Oversight Board (AOB) came into being on April 1, 2010 under the Securities Commission Amendment Act 2010. The AOB is

\footnotetext{
* Acknowledgement: This paper is funded by UPM FRGS research grant scheme for which the authors gratefully acknowledge. Grateful thanks are also extended to all auditors who participated in the study without whose cooperation and knowledge sharing willingness, the study would not have been executed successfully.

Hashanah Ismail, lecturer, Faculty of Economics and Management, Universiti Putra Malaysia. Email: hashanah@upm.edu.my. Mazlina Mustapha, Ph.D., Faculty of Economics and Management, Universiti Putra Malaysia.
} 
an oversight mechanism to regulate and oversee the proper financial reporting of public interest entities (PIEs). Although the AOB is a recent institution, similar independent audit oversight boards have been established in several jurisdictions, such as in Australia, Holland, Japan, Canada, the UK, and the US, all of which have the same function: to monitor the processes used by participating audit firms in respect of compliance with auditing standards and legal obligations relating to audit and audit quality. Studies on whether audit quality has improved with the establishment of an audit oversight body are limited. Verschoor (2012) reported that audit quality has not improved in the post Sarbanes-Oxley era in the US, and Kleinman, Lin, and Palmon (2014) expressed doubts as to whether auditing practices have improved as a result of annual inspections by an oversight board in the various jurisdictions. Given that the AOB is now another layer of regulation to the existing regulatory framework of audit in Malaysia, how do auditors respond to the prospect of being audited by a regulatory body? It is the objective of this paper to examine the expectations of external auditors of the AOB and its oversight role in enhancing audit quality in Malaysia. Specifically, the study seeks the views of auditors on relatively new requirements to register themselves as fit and proper persons to audit PIEs, to prepare themselves for inspection of compliance with International Standard on Quality Control (ISQC), to have AOB review audit engagements, and to be prepared for a review of audited financial statements and the consequences of not complying with any of the AOB's requirements. The rest of the paper is organized as follows: The next section reviews some of the literature on audit quality and the regulatory framework of auditing. This is followed by a description of the methodology of the study. The paper then discusses the results and finally concludes.

\section{Literature Review}

Audit quality is viewed as one of the important factors affecting the credibility of audited financial statements (Arrunada, 2004). If a quality work is performed, then the audited financial statements would be given an appropriate report rendering the financial statements useful to users for decision-making. DeAngelo (1981) defined audit quality as having twin dimensions of the probability that the auditors are competent to be able to detect material misstatements and having detected the misstatements, they are willing to report it, that is upholding auditor independence. According to DeAngelo (1981), big 8 audit firms (then) provide better quality audit than the non-big 8 , as the former have a reputation to protect and clients pay bigger fees to non-big 8 firms, because the audited financial statements have a higher credibility.

The quality of audit is regulated at many levels through a number of rules, regulations, and the law, and for specialized sectors such as the financial institutions, an additional layer of regulation is imposed by the central bank. In Malaysia, several provisions in the Companies Act 1965 mandate that auditors must have competence and the necessary skills before accepting nominations to be appointed as auditors. In addition, the law also upholds the auditors' independence by giving auditors certain rights, such as the right to seek information, to attend general meetings concerning the audit, and to be heard if dismissed. The law empowers the MIA to prescribe the competence criteria. At the professional level, external auditors must have a practicing license and are governed by the rules of the institute and the by-laws on professional ethics, conduct, and practice of the institute. As MIA is a member of International Federation of Accountants (IFAC), it also adopts and implements international and national standards on auditing and assurance. These standards embrace a set of globally recognized quality audits. Hence, all audits are required to be performed in accordance with approved auditing standards issued by MIA, thus communicating to users of audit reports that a minimum 
benchmark has been complied with. ${ }^{1}$ Auditors are required to declare positively in the auditors' report that the audit was carried out in accordance with approved auditing standards in Malaysia, and any departure or non-compliance with extant auditing standards will have to be justified. In July 2006, MIA adopted the ISQC which audit firms must use. This standard prescribes quality elements of the audit at a firm level. In addition, the members of the profession are also bound by the Code of Ethics under the MIA by-laws to uphold auditor independence and integrity. Hence, regulation relating to audit quality before the AOB was established spanned both the individual and firm levels and the profession was largely a self-regulating profession where the profession itself was not only the standard setter but also the monitoring body for compliance with the profession's rules and the Code of Ethics. The profession would impose sanctions on members for failure to perform quality audit work as prescribed by extant auditing standards.

In April 2010, the AOB commenced operations. It was set up under Section IIIA of the Securities Commission Act 1993 to oversee the auditors of PIEs and promote confidence in the quality and reliability of PIE's audited financial statements. In 2010 too, AOB was admitted as a member of the International Forum of Independent Audit Regulators. It would have the power to reprimand auditors who had done wrong including issuing penalty and deregistering auditors from practice. AOB is, therefore, the auditor which audits the auditors and its incorporation added another layer to the regulatory framework for external audit in Malaysia, making audit regulation no longer entirely one of self-regulation but co-regulated between the profession and the law.

\section{Methodology}

Data for this study are obtained from interviews with partners and managers of both big 4 and non-big 4 audit firms in the Klang Valley on their expectations and reservations as to how AOB can enhance audit quality of PIEs. Secondary data are sourced from publications of the AOB annual reports and press release by the Securities Commission. As the sample is relatively small, no statistical analysis is used, but data are coded and analyzed qualitatively around the four dimensions of quality framework as indicated by the AOB.

\section{Findings and Discussion}

Overall, there are mixed positive and negative expectations expressed by respondents. The positive note reflects a belief that increased regulation can enhance audit quality, provided that the AOB employs the right people for the job. The downside of increased regulations is increased cost of compliance. Auditors agree that one of the possible impacts of the AOB's presence will be that all audit firms will face a gigantic task to prepare themselves to raise the standards of the practice, if audit firms wish to be appointed as auditors of PIEs. Based on reports of practice reviews, audit firms have fared poorly. The AOB also expects audit firms to implement more new processes and documentation such as manuals, templates, checklists, and model working papers in compliance with the standards in ISQC. In addition, there must be at least three auditors working on a single listed company's audit. The additional costs could lead to an increase in audit fees. Costs are also expected to increase, because audit firms must show a calendar of yearly training plans and monthly human resource reports including training needs analysis. According to one respondent from a non-big 4 audit firm, "Stringent compliance requirements will create new layers of processes which in turn will impact costs

\footnotetext{
${ }^{1}$ Retrieved from http://www.mia.org.my.
} 
although we concur that it will improve audit quality in Malaysia”. This is similar to a finding by Riley, Jenkins, Roush, and Thibodeau (2008) which reported that inspections by the Public Company Accounting Oversight Board (PCAOB) in the US have increased costs of preparing for the audit by as much as 400 hours. Another respondent agreed that along with the AOB comes a $30 \%$ increase in the overall costs of auditing public companies.

That audit quality will improve is agreed by a big 4 respondent: “The importance of independent oversight boards in enhancing the quality of audits and promoting investor confidence is widely recognized based on the experience of other countries", and a non-big 4 respondent echoed the sentiment by saying that they welcome the AOB.

Reservations were also expressed by a non-big 4 respondent that AOB could lead to reinforcing the stranglehold that large audit firms have over the audit market for PIEs. Another grouse was that the regulators should consider the adequacy of existing regulations and that currently, monitoring under existing laws is still ineffective, so why add more regulations?

In anticipation of the greater monitoring by $\mathrm{AOB}$, auditors are now increasingly willing to qualify accounts which do not comply with extant accounting standards (The Star, 2011).

What AOB has achieved towards ensuring a robust oversight of auditors over the period since April 2010 covers five areas: registration of auditors, inspection of compliance with ISQC 1 by audit firms, review of audit engagement, monitoring of financial statements issued by PIEs, and sanctions for any failures to comply. In order to ensure that audits of PIEs are performed to quality standards, the AOB mandates that all audit firms and individuals must first of all be registered with the AOB. All audit firms are required to show as evidence to the AOB that the firms have complied with ISQC 1, whilst all individual auditors must show that they possess the competence to audit the financial statements of PIEs. In addition, individual auditors must not have been convicted of any offence involving fraud or dishonesty. Hence, before an audit firm can accept nomination for appointments to be auditors, the firms must have successfully been registered with the AOB first. In its first year of operations, five audit firms which failed to register but accepted nomination for appointments to be auditors of PIEs were sent show cause letters by the AOB, thus sending very strong signals to the community that it meant business. As at December 31, 2010, 83 audit firms and 310 individuals have registered with the AOB according to the AOB Annual Report (AOB, 2010).

Inspection of audit firms (all big 4 and two others with more than 10 partners) revealed that a number of shortcomings were identified especially those relating to adequate audit documentation and evidence for significant judgments made. Lack of evidence to support audit conclusion is a manifestation of dysfunctional audit behavior which impairs audit quality. AOB also revealed that the level of skepticism exercised is still inadequate especially in relation to audits of estimates and assumptions, for example, fair value, impairment, and going concern.

Two years after its establishment, AOB issued a sanction to an auditor for failure to comply with the relevant auditing standards in Malaysia. However, which standards were not complied with and why the auditor was reprimanded were not explained. Subsequent press report indicated that the issue revolves round the use of the going concern assumptions. The appropriateness of the going concern assumption in the preparation of financial statements is a critical and difficult stage of the audit, as a lot of judgments are involved. AOB reports that auditors do not appear to challenge key assumptions used by management to support the basis for using the going concern assumption. 


\section{Conclusion}

The establishment of the AOB in Malaysia has changed the oversight of the auditing profession from one as a self-regulating profession to that of a co-regulatory environment. Auditors of PIEs in Malaysia now work in an environment of co-regulation: a mixture of independent regulation by the AOB and complemented by the profession. Though the presence of the AOB is considered positive in that it will increase audit quality, there is also a concern that it will also lead to an increase in audit fees. In its early years of service, the AOB has ensured that only fit and proper persons can register as auditors of PIEs, reviewed audit engagements, and sanctioned non-compliance with auditing and ethical standards. The reports of AOB suggest that expectations of improvement in audit quality are showing positive results despite the concern expressed by auditors that costs will increase driving up audit fees. As audit quality has many dimensions, future studies may consider examining financial reporting quality before and after AOB to see whether audited financial statements have improved post AOB.

\section{References}

Arrunada, B. (2004). Audit failure and the crisis of auditing. European Business Organization Law Review, 5(4), 635-643.

Audit Oversight Board [AOB]. (2010). AOB annual report 2010. Retrieved from http://www.sc.com.my

DeAngelo, L. E. (1981). Auditor size and audit quality. Journal of Accounting and Economics, 3(3), 183-199.

Kleinman, G., Lin, B. B., \& Palmon, D. (2014). Audit quality: A cross-national comparison of audit regulatory regimes. Journal of Accounting, Auditing, and Finance, 29(1), 61-87.

Malaysian Institute of Accountants [MIA]. Retrieved from http://www.mia.org.my

Riley, R. R., Jenkins, J. G., Roush, P. Y., \& Thibodeau, J. C. (2008). Audit quality in the post-SOX audit environment: What your auditing students must know about the PCAOB inspection process? Current Issues in Auditing, 2(2), A17-A25.

The Star. (2011, May 4). A number of firms have accounts qualified. The Star, B6.

Verschoor, C. (2012). Has SOX been successful? Strategic Finance, 94(3), 15-17. 